\title{
THE DELIVERY REQUIREMENT: AN ILLUSORY BAR TO REGULATION OF MANIPULATION IN COMMODITY EXCHANGES*
}

MaNipULATION on commodity exchanges, when accomplished by the intentional use of economic power to influence market prices for private gain, is an activity so like ordinary market behavior in many of its manifestations that, while it is prohibited by federal statute, ${ }^{1}$ courts have had considerable difficulty in determining what acts are proper indicia of its occurrence. ${ }^{2}$ In the recent case of Volkart Bros. v. Freeman, ${ }^{3}$ the Fifth Circuit Court of Appeals faced these recurrent problems, expressing great caution about disturbing the market's ordinary operation by too broad enforcement of anti-manipulation rules. 4 To understand the court's treatment of the manipulation problem, then, it is first necessary to understand the ordinary operation of commodity exchanges.

Commodity exchanges are markets for the purchase and sale of rights to receive and deliver such commodities as cotton or grain during a specified future "delivery month," up to eighteen months distant.5 Though variations

*Volkart Bros. v. Freeman, 311 F.2d 52 (5th Cir. 1962).

1. 49 Stat. 1491 (1936), as amended, 7 U.S.C. \$§ 1-17(a) (1958).

2. See, e.g., General Foods Corp. v. Brannan, 170 F.2d 220 (7th Cir. 1948), where the court, faced with a charge of attempted manipulation of rye prices, held, after an exhaustive investigation, that no manipulation had occurred; and Great Western Food Distrib., Inc. v. Brannan, 201 F.2d 476 (7th Cir.), cert. denied, 345 U.S. 997 (1953), where an examination of price differentials, commercial practices and the petitioners' conduct and statements compelled a finding of manipulation. The problems of excessive speculation, manipulation and consequent price fluctuations seem to have accompanied futures trading (trading on commodities exchanges) since it first developed in Chicago shortly before the Civil War. Futures trading grew from the practice of trading in grain "to arrive" at a subsequent date. This practice was necessitated by poor transportation conditions during the nineteenth century, and vastly encouraged the already popular speculation in grain. With the development of contracts which were to be satisfied at some time in the future, "short" sales by speculators who did not own grain at the time of the transaction became possible. Schemes to dominate prices were by no means uncommon. See generally, Horfaran, Future Trading upon Organtzed Comarodtty Markets in the United States, 13-23 (1932). Similar operations in commodities other than grain have not been uncommon. See Hubbard, Cotton and the Cotton Market 392-96 (2d ed. 1927).

3. 311 F.2d 52 (5th Cir. 1962).

4. See $i d$. at $59-60$.

5. Such a transaction on its face obligates the seller to deliver to the purchaser warehouse receipts for the agreed-upon quantity of the commodity at any time during the delivery month. BaEr \& Saxon, Commodity Exchanges and Futures Trading 135 (1949). See also Brief for the New York Cotton Exchange, as Amicus Curiae p. 5, Volkart Bros. v. Freeman, 311 F.2d 52 (5th Cir. 1962) (hereinafter cited as Exchange Brief). Few major works have appeared on futures trading and commodity exchanges in general. The most prominent are HofFman, op. cit. supra note 2, and BAER \& SAxon, supra. Several articles treat various aspects of futures trading and its regulation. See, e.g., Campbell, Trading in Futures ander the Commodity Exchange Act, 26 Geo. WASH. L. REv. 215 
occur, the movement of prices on these "futures" markets parallels price changes on the actual, or spot, markets where physical goods are traded. ${ }^{6} \mathrm{By}$ virtue of this relationship, the exchange serves as a source of insurance against disastrous price changes for merchants or others engaged in spot transactions. ${ }^{7}$ Thus, a buyer of physical wheat, to hedge himself against a fall in the price of wheat which he will be unable to sell for a period of time, will sell wheat futures at the time he makes his commodity purchase. When he later sells the actual wheat, he will make corresponding purchases of wheat futures, that is, "offset" the original sale of futures. ${ }^{8}$ Assuming that the futures-spot price relationship has remained stable, the effect of any change in commodity prices will be compensated by the effect of the hedger's reverse transaction in the futures market. Similarly, if, prior to purchasing wheat, a grain merchant has committed himself to delivery, he may purchase wheat futures at the time of his commitment to insure himself against a price increase. When he is ready to buy the physical grain he will sell his futures. Assuming again that the futuresspot price relation has remained constant, the merchant will be compensated for any possible loss on his spot transaction by a profit on the futures exchange. ${ }^{9}$ Although hedging his spot commitments on the futures exchange may on occasion result in a merchant's losing potential profits from spot price fluctuations, such tosses will not concern him, since he desires to make his profits not by speculating on price changes but rather from purchases and sales of commodities. ${ }^{10}$ Speculators, on the other hand, enter the futures exchanges in significant number, precisely for the purpose of profiting from such price fluc-

(1958) ; Irwin, The Nature of Risk Assumption in the Trading on Organized Exchanges, 27 Am. Econ. Rev. 267 (1937) ; Working, Futures Trading and Hedging, 43 AMr. Econ. Rev. 314 (1953) ; Working, New Concepts Concerming Futures Markets, 52 Axr. EcoN. REv. 431 (1962) ; Comment, Federal Regulation of Commodity Futures Trading, 60 YaLE L.J. 822 (1951) ; Note, 64 YALE L.J. 906 (1955) ; Comment, Manipulation of Commodity Futures Prices-The Great Western Case, 21 U. Chr. L. Rev. 94 (1953).

6. Howell, Price Risks for Cotton and Cotron Products 23; U.S. Dep't of Agriculture, Trch. Bull. No. 1119, (1955).

7. Hoffman describes exchange operations thus: "The entire activity of future trading consists in either assuming risk as speculators or shifting risk as hedgers." HoFfaran, op. cit. supra note 2, at 4. See also Working, Futures Trading and Hedging, 43 Ax. Econ. Rev. 314, 315 (1953) ; HowelL, op. cit. supra note 6.

8. Despite the terms of the contract noted supra note 5 , an "offset" is an acceptable alternative to delivering warehouse receipts. See Board of Trade v. Christie Grain \& Stock Co., 198 U.S. 236, 246-48 (1905).

9. This method of insurance is not complete. At times, due to inexact responses to the largely identical conditions which infuence both futures and spot markets, prices may not change proportionately, and the hedger will thus gain or lose somewhat on his hedge. Merrill Lynch, Pierce, Fenner \& Smith, Inc., How to Hedge Commodities 17-19 (1961). Occasionally, though rarely, changes in the futures-spot price relationship (the basis) exceed spot price changes, in which case the trader risks more by hedging than by not doing so. There is little question, however, that basis risks are normally far smaller than the price risks avoided by hedging. BAER \& SAXoN, op. cit. supra note 5, at 206, 219-29.

10. See Merrill Lynch, Pierce, Fenner \& Smith, Inc., op. cit. supra note 9, at 10. 
tuations. The speculator plays an important role on the exchange by swelling the volume of trading and providing the liquidity necessary to its smooth functioning. 11

Because of the peculiar functions the futures market fulfills for its participants, delivery of the actual commodity during the delivery month is an event unexpected and undesired by the ordinary trader. ${ }^{12}$ A speculator would be hard put to meet a delivery requirement, and he is totally unprepared to take delivery. A hedger selling futures will doubtless prefer using the stocks in his possession for processing or a sale on the spot market to delivering them on the futures exchange. ${ }^{13}$ The buyer of futures will desire delivery even less, since according to the terms of the futures contract, a range of qualities can be delivered, on any day during the delivery month ${ }^{14}-$ a situation which makes purchase of actual commodities on the futures exchange highly unattractive to a merchant with specific needs at specific times. ${ }^{15}$ Despite this hostility to bringing actual commodities into futures dealings, the standard futures contract contains the terms of an ordinary sales agreement $;^{16}$ if the contract is not offset before the last day on which trading in that future is allowed by the

11. BAER \& SAXoN, op. cit. supra note 5, at 53-54; Campbell, supra note 5, at 219-29. Speculation, despite its clear necessity to the smooth operation of exchanges, has been severely attacked for causing price fluctuations and high futures prices. BAER \& SAxON, op cit. supra note 5 , at 55-58.

12. Working's discussion of futures trading is significant. He regards its basic function as promoting economy and convenience in hedging and speculation. Any other definition, he believes, tends to obscure and confuse the distinction between futures trading and other types of commodity operations. Working, Futures Trading and Hedging, 43 AM. Econ. Rev. 314, 315-17 (1953). See also, Comment, Federal Regulation of Conmodity Futures Trading, 60 YaLe L.J. 822, 839 (1951) ; Hoffaran, op. cit. supra note 2, at 314. One commentator has even hypothesized that in a perfectly functioning futures exchange, no deliveries would occur. BAER \& SAXoN, op. cit. supra note 5, at 210.

13. See Merrill Lyvch, Pierce, Fenner \& Samth, INc., op. cit. supra note 9, at 37.

14. Baer \& Saxon, op. cit. supra note 5, at 133-34; N.Y. CotTon Exchange, Bylaws (as amended, 1932) $\$ 120$ (F) ; App. to Brief for Respondents, p. 23, Volkart Bros. v. Freeman, 311 F.2d 52 (5th Cir. 1962) (hereinafter cited as Respondents' App.). The rule as to delivery of a variety of grades has a strong justification : it makes it more difficult for buyers to buy up all deliverable commodities and execute manipulative "corners." See infra note 25 and accompanying text. Hoffaran, op. cit. supra note 2, at 318-19. For a good example of the need for this rule, see 7 FTC, Report on The Grain Trade 251 (1926).

15. Occasional traders, of course, are either in a position in which they can or may even desire to take delivery. They may have constantly varying commitments and may find it profitable to take delivery on some contracts when commodities are needed promptly and purchase on the spot market is for some reason inconvenient. See Corn Products Refining Co. v. Commissioner, 350 U.S. 46, $48-49$ (1955). Similarly, merchants who buy and sell varying qualities may be undisturbed by the inability to know certainly what grades they will receive. Even these traders will be discouraged somewhat from taking delivery, however, by the fact that deliveries are normally of the lowest quality acceptable and hence may not be of use to the trader who receives them. See BAER \& SAXON, op. cit. supra note 5 , at 137 .

16. For typical futures contracts, see $I d$. at 134-35; N.Y. CoTTon Exchange, op. cit. supra note 14, at $\$ 119$. 
exchange-or if a trader insists on literal satisfaction of his contract rightsit must be fulfilled by conveyance of the physical commodity. ${ }^{17}$ The exchanges provide substantial penalties, in addition to ordinary contract damages, against those who fail to meet their delivery obligation. ${ }^{18}$

Retention of the delivery requirement is beneficial, since it works to maintain the general equivalence of futures and spot prices which is necessary if hedgers are to be protected effectively against losses arising from price fluctuations. This equivalance is occasionally disrupted by fluctuations in the futures price unrelated to price movements on the spot market. If the futures price advances significantly above the spot price, traders will be induced to "spread" - to buy quantities of the actual commodity at the relatively low price and simultaneously to sell futures. Later, they may make delivery on their futures contracts with the spot commodity purchases, or, if the normal futures-spot price relationship has been restored, offset and sell their spot holdings, in either case reaping a considerable profit. The influx of futures sales and spot purchases in response to the nearly certain profit which this situation offers, generally tends to bring the futures and spot prices together..$^{19}$ Similarly, if the futures price drops significantly below the spot price, futures will be bought and spot commodity sold. If this activity is not sufficient to drive prices back together, a further impetus toward restoration will usually develop as futures purchasers refuse to offset in the final days of trading, inducing sellers to bid the futures price up in order to avoid the often substantial inconvenience of delivery. ${ }^{20}$

Although the market has this corrective mechanism, the disruptions of the futures-spot price equivalance which do occur impair the success of market operation. Such disruptions may be caused by factors, such as the threat of

17. Indeed delivery, if desired, is assured in every exchange by a clearing house system, which, at the end of each trading day, clears all contracts, inserting itself into each transaction as buyer to every seller, and seller to every buyer. By essentially replacing both parties to each agreement, it is able to guarantee performance on both sides. Its operations are largely financed by the depositing of margin with the clearing house by each member to assure performance of his contracts. For a detailed discussion of the clearing house, see BAER \& SAXoN, op. cit. supra note 5, ch. 9.

18. Respondent's App. at 131.

19. Hofman, op. cit. supra note 2 , at 256-58; Howeld, op. cit. sutpra note 6, at 24 .

20. Though most dislocations in which futures prices are relatively low can be corrected merely by purchasers waiting until late in the delivery month to liquidate, such dislocations have occasionally persisted for several months, even when spreading was used and delivery demanded. See Horfman, op. cit. supra note 2, at 257-58. This operation is also frequently utilized by intelligent speculators to profit from price imbalances between two separate futures markets, or two separate futures within the same market. Some price relationship normally exists between various markets for a single future and between various months of the future on the same exchange. Although these relationships are not as clear-cut as that between spot and futures prices, clear price imbalances sometimes occur, and traders can profit from them, in the first case, by buying on a low market and selling on a high one, or, in the second, by purchasing futures of the abnormally low month, and selling those of the high one, liquidating all interests when the imbalances are cured. BAER \& SAXoN, op. cit. supra note 5 , at 41-42. 
war, which are beyond the control of futures traders. ${ }^{21}$ But other price movements may be the result of such deliberate trader activity as the spreading of rumors, undertaken to influence the market price for the trader's benefit. ${ }^{22}$ Similarly, traders, by failing to offset during the last days of trading in a future, may obtain substantial control of outstanding issues in order to capitalize on the usual seller unpreparedness for delivery. ${ }^{23}$ The inconvenience of late preparation for delivery induces the sellers to bid up offset prices in a lastminute effort to avoid having to deliver, yielding substantial profit to the trader who has held out. ${ }^{24}$ If the trader has simultaneously purchased a sufficient quantity of the commodity in the spot market to dry up the sources of deliverable goods, the operation is denoted a "corner" ;25 if the futures market

21. Dislocations related to war or national disaster may create severe shortages and drive prices up sharply. Though some such dislocations have occurred on the New York Cotton Exchange, on which Volkart Bros.' contested operations took place (Exchange Brief, pp. 20-21, n.6), the rarity of these occurrences and the fact that manipulative operations are usually unrelated to them make further reference to this sort of operation unnecessary. Less severe disruptions can occur as a result of inexact responses of the two markets to the largely identical forces which influence them. For an outline of some factors which can affect the markets differently, see Merrill Lynch, PIerce, Fenner \& Surth, op. cit. supra note 9, at 18. See also HoweLL, op. cit. supra note 6, at 24-27.

22. See 7 FTC, Report on the Gratn Trade 256-58 (1926). For examples of these operations see Reuben Earl McGuigan, 5 Agri. Dec. 249 (1946); Ralph W. Moore, 9 Agri. Dec. 1299 (1950), aff'd, Moore v. Brannan, 191 F.2d 775 (D.C. Cir.), cert. denied, 342 U.S. 860 (1951).

23. Comment, Manipulation of Comnodity Futures Prices-The Great Western Case, 21 U. CHI. L. Rev. 94, 95 (1953) ; see HofrMan, op. cit. supra note 2, at 315-18.

24. It should be noted that sellers can, on occasion, panic buyers and thus drive prices down to their profit. Sellers accomplish this operation by issuing warehouse receipts in large numbers at the start of a delivery month. These are distributed by the clearing house of the exchange among outstanding buyers. See supra note 17. If a buyer does not wish delivery, he must, within a half-hour, sell a quantity of futures equal to the warehouse receipt and deliver the receipt to the new buyer. If large numbers of warehouse receipts are delivered to purchasers unwilling to take delivery, panic selling and a fall in prices might occur. Comment, Manipulation of Commodity Futures Prices-The Great Western Case, 21 U. Crr. L. REv. 94, 102 (1953) ; BAER \& SAXoN, op. cit. supra note 5, at 182-84; see HoffMan, op. cit. supra note 2, at 314-15. This procedure, however, at least has the advantage of informing buyers explicitly that delivery is to be made. When a purchaser desires delivery, on the other hand, he merely fails to offset his interest. Sellers are influenced to drive up prices in a rush to offset, not so much due to an explicit indication by the buyer, but merely due to the time deadline which forces them either to deliver or offset before the end of the delivery month. The potentially powerful position in which this ambiguous situation may put purchasers leaves it not immune to criticism. See infra note 73.

25. Some very extreme examples of the corner have occurred. See e.g., Great Western Food Distribs, Inc. v. Brannan, 201 F.2d 476 (7th Cir.), cert. denied, 345 U.S. 997 (1953). In that case, petitioners bought large interests in both the spot and futures egg markets in Chicago. They ultimately controlled better than half the deliverable spot supply and about $75 \%$ of the December futures, positions which enabled them to demand handsome premiums for liquidation. G.H. Miller \& Co. v. United States, 260 F.2d 286 (7th Cir.), cert. denied, 359 U.S. 907 (1959) (another corner of egg futures) ; Peto v. Howell, 101 F.2d 353 (7th Cir. 1938) (a massive corner in the corn market) ; and United States v. Patten, 226 U.S. 525 (1913) (a cotton corner). 
alone is dominated, the trader's action is referred to as a "squeeze". ${ }^{26}$ The sharp, if brief, price fluctuation which results from such conduct or from the equivalent activity of a large seller of futures who begins to issue notices of delivery which purchasers are anxious to avoid, can also be caused unintentionally. Thus, when merchants fail to liquidate their holdings of futures because spot transactions have not been completed until shortly before the close of trading, their late holding may lead sellers, fearing that delivery may be demanded of them, to bid up prices in attempts to offset. ${ }^{27}$ Whether intentionally or unintentionally caused, the price fluctuation, by disturbing the expectations of both hedgers and speculators, can cause considerable harm.28

Recognition of this harm led Congress to adopt regulatory measures, now principally embodied in the Commodity Exchange Act of $1936,{ }^{20}$ which provides both administrative and penal sanctions against those who "manipulate or attempt to manipulate the price of any commodity."30 Price manipulation is not explicitly defined in either the statute or its legislative history. The courts and the judicial officer of the Department of Agriculture who administers the regulatory scheme have nonetheless given substance to the concept, defining manipulation to include "any and every operation or transaction or practice calculated to produce a price distortion of any kind in any market

26. Though squeezes are rarely so specifically defined (BAER \& SAXON, op. cit. supra note 5 , at 83 , define them as "a relatively small corner"), the circumstances of virtually all squeezes indicate that not even "relatively small" control of the spot market is characteristic. For examples, see Hofrman, op. cit. supra note 2, at 316; Hubbard, op. cit. supra note 2 at 396; Merrill Lynch, Pierce, Fenner \& Simith, op. cit. supra note 9 at 37-38; see also definition of Senator Pope, 80 Corvg. Rec. 8089 (1936). Since control of the spot market is not involved, these operations can often be defeated either by the shorts' performance of their contracts through delivery or by the replacement of existing shorts by merchants with large spot holdings who can then deliver; still, some premiums can usually be exacted before either of these processes is initiated. See, e.g., Hurbard, op. cit. supra note 2, at 396.

27. See Merrill Lynch, Pierce, Fenner \& Simith, Inc., op. cit. supra note 9, at 36-37.

28. Evidence of the damage of futures price dislocations is abundant. Speculators may be driven out of the market by such fluctuations. Comment, Manipulation in Commodity Futures Prices-The Great Western Case, 21 U. CHI. L. Rev. 94, 102 (1953) ; Huebner, Corners, 4 Encrc. Soc. Scr. 409 (1931). And hedgers will pass the burden of such dislocations, which are often significant, on to consumers in the form of higher prices. See HowerL, op. cit. supra note 6, at 30-33; Hofrman, op. cit. supra note 2, at 4. For a typical example of the manner in which a hedger may find himself in the market at the time a future is maturing, when the price dislocations may be most sudden, see Merrill Lyncr, PIERCE, FENNER \& SMITH, op. cit. supra note 9, at 36-38.

29. 49 Stat. 1491 (1936), as amended, 7 U.S.C. $§ \S 1-17$ (a) (1958). Its forerunner was the Grain Futures Act, 42 Stat. 998 (1922), which survived constitutional attack in Board of Trade v. Oisen, 262 U.S. 1 (1923).

30. 49 Stat. 1501 (1936), as amended, 7 U.S.C. $\$ 13$ (1958); see also 42 Stat. 1002 (1922), as amended, 7 U.S.C. $\$ 9$ (1958). There is considerable evidence that the elimination of price manipulation was the prime force in moving Congress to adopt regulatory measures. See 42 Stat. 999 (1922), 7 U.S.C. \$ 5 (1958) ; H.R. Rep. No. 421, 74th Cong., 1st Sess. 1-3 (1936); 62 Conc. Rec. 9406, 9414 (1922) ; 80 Cong. Rec. 6161, 6164 (1936) (remarks of Senator Pope). 
either in itself or in relation to other markets". ${ }^{31}$ In its broad sweep, this definition includes all intentional, while excluding all inadvertent, activity. ${ }^{32}$ Such a distinction, based on the intent of the trader, is entirely consistent with the congressional aims in enacting regulatory legislation ;3 it also comports with the understanding of traders themselves, who regard activities such as the squeeze as manipulative. ${ }^{34}$ Under this definition, a determination of manipulation does not depend on the price pattern on the futures exchange $;^{3 \mathfrak{5}}$ theoretically, if the requisite showing of intent can be made, activity is proscribed even if it has the result of halting damaging discrepancies between price movements on the futures and spot markets. ${ }^{36}$ The definition has decided advantages over other standards, such as the causing of any price change; by excluding inadvertent actions, it neither penalizes functional and occasionally necessary transactions on the exchange by hedgers, nor discourages the beneficial operations of speculators. ${ }^{37}$

While this formulation, focusing on intent, includes the squeeze within proscribed activity, it might create substantial problems of proof, with a resulting risk of interference with market operations, if no workable standard could be found for determining intent in squeeze situations. ${ }^{38}$ One method of avoiding this problem would be to include within the definition only those operations in which a trader creates as well as exploits a potentially dangerous

31. Volkart Bros. v. Freeman, 311 F.2d 52, 58 (5th Cir. 1962). See also General Foods Corp., 6 Agri. Dec. 288, 305 (1947).

32. Great Western Food Distribs. v. Brannan, 201 F.2d 476, 483-84 (7th Cir.), cert. denticd, 345 U.S. 997 (1953).

33. The fact that the legislators in 1922 showed considerable concern over basing sanctions on a finding of knowing malfeasance supports the view that a showing of intent to manipulate should be required before sanctions are imposed. See 62 CoNG. REc. 9407, 12568 (1922).

34. 7 FTC, Report on the Grain Trade 219 (1926) ; Comment, Manipulation in Commodity Futures Prices-The Great Western Case, 21 U. Cur. L. Rev. 94, 99-100 (1953).

35. See, e.g., General Foods Corp. v. Brannan, 170 F.2d 220 (7th Cir. 1948), where the court, in reversing an administrative finding of manipulation of rye futures, concerned itself only slightly with the price effects of petitioners' conduct and devoted primary attention to their state of mind. Similarly, in Moore v. Brannan, 191 F.2d 775 (D.C. Cir.), cert. denticd, 342 U.S. 860 (1951), the Court of Appeals, in affirming a suspension of trading privileges, ignored the fact that petitioner's attempt to influence prices by circulating false rumors as to federal agricultural policy had failed. See Ralph W. Moore, 9 Agri. Dec. 1299 (1950).

36. Such a showing may often be nearly impossible to make, however; the problems any court normally encounters in inferring a party's state of mind from his conduct will be multiplied where prices had been returning to their normal pattern and the defendant's conduct thus approximates normal market behavior.

37. Such developments, of course, would hardly be salutary, considering the valuable role played by speculators and the functional use of the exchange by hedgers. See text accompanying notes 7-11 stpra. If there were no intent requirement, such a development would seem inevitable, since the effect of one's conduct would be the only criterion, leaving the standard merely the unreasonableness of the price change caused by one's actions. In addition, a constitutional objection might be raised to a definition. It might be attacked as so vague that traders could not be sure what actions were legal and what were not.

38. See note 37 supra. 
situation. Thus, where a trader has spread rumors or cornered the market by buying up the available supply of a spot commodity-where he has, in other words, prepared the market for exploitation-there will be little problem in finding manipulation. Such action is largely inconsistent with any rational motive other than a desire to influence prices. ${ }^{39} \mathrm{~A}$ squeeze, on the other hand, involves no such preparation of the market for exploitation; although the deliberate holding of a large futures position late in the delivery month, playing upon seller expectation that delivery will not be required, is recognized as manipulative, it will often appear so like ordinary market behavior that substantial problems of proof, along with a substantial risk of penalizing necessary market behavior, will come into existence if regulation is essayed. The manipulator is not likely to have given direct evidence of his intent, and the state of his mind must therefore be ascertained by reference to his conduct. But late holdings are in many circumstances an expected manifestation of the market's ordinary price correction mechanism. And they may also result from a merchant's late failure to liquidate a hedge. The narrower definition of manipulation, which would exclude squeezes by requiring evidence of creation of market weaknesses as well as intent to exploit, would not so much deny that squeezes are manipulative or harmful, ${ }^{40}$ as hold that they can not be sieved out of everyday market behavior without inordinate cost to market functioning.

It was this problem of definition which appeared to trouble the Fifth Circuit Court of Appeals in Volkart Bros. v. Freeman; ;1 its decision was so broadly stated as to deny the possibility of government regulation of squeeze situations. ${ }^{42}$ Volkart Bros. was a highly experienced and respected cotton brokerage firm which traded on the commodities exchange and also had extensive dealings in the wholesale cotton market. ${ }^{43}$ In early October, 1957, Volkart held a significant bloc of October cotton futures on the New York Cotton Exchange. ${ }^{44}$ While other purchasers were liquidating their interests, diminishing the total volume of futures contracts outstanding, Volkart Bros. not only retained its New York holdings, but simultaneously made a large purchase of

39. Such operations are usually so extreme that their purpose cannot easily be disguised. See examples cited notes 22 and 25 supra.

40. In addition to the clear congressional desire to eliminate all manipulation (supra note 30 ), the Federal Trade Commission, in its exhaustive study of the grain trade, expressed a desire to eliminate squeezes, though without specifying a method of doing so. 7 FTC, Report on the Grain Trade 271 (1926).

41. 311 F.2d 52 (5th Cir. 1962).

42. Id. at 59.

43. Volkart had large cotton stocks and commitments, both foreign and domestic, although its interest in the spot market in October, 1957, was relatively small, constituting less than $10 \%$ of the stock of certificated spot cotton. It was a member of both New York and New Orleans cotton exchanges. Volkart Bros., 20 Agri. Dec. 306, 324-25 (1961); Respondents' App., p. 85; Exchange Brief, pp. 24, 61. These dual occupations, it might be noted, put Volkart in the advantageous position of being able to take delivery on futures contracts without suffering undue inconvenience, a position necessarily highly beneficial to any trader bent on influencing prices by a squeeze. Hofraran, op. cit. supra note 2 , at 316 .

44. Respondents' App., p. 34. 
futures on the New Orleans Cotton Exchange. ${ }^{45}$ By October 11, the stock of cotton certificated, and thus readily available for delivery by sellers who failed to offset, amounted to less than half of Volkart's combined New York-New Orleans interest. ${ }^{46}$ Throughout October, it announced its willingness to offset only at a price slightly above the market price. ${ }^{47}$ And on the final day of October trading, Volkart's prices were raised to even higher over-all levels, which became the market price due to the firm's substantial holdings. By these operations, Volkart was able to reap a profit of over $\$ 20,000$ on the final day of trading. ${ }^{48}$ In a proceeding stimulated by the complaints of the "squeezed" sellers, the Judicial Officer of the Department of Agriculture found Volkart Bros. guilty of having manipulated prices. Its trading privileges were suspended for fifteen days. ${ }^{49}$

Although the Fifth Circuit held on review that "the weight of the evidence does not support the findings that petitioners manipulated or attempted to manipulate futures prices . . .,"50 its opinion does not otherwise evidence the re-examination of factual findings which would normally be expected where an administrative ruling is reversed on the facts. ${ }^{51}$ The court did not demonstrate

45. Ibid.; Volkart Bros. 20 Agri. Dec. 306, 317 (1961).

46. Volkart Bros. v. Freeman, 311 F.2d 52, 56 (5th Cir. 1962). The only alternative to offsetting or delivery of certificated cotton which remained for sellers was to arrange for delivery of cotton which had not yet been certificated; issue to futures holders transferable notices for this cotton, estimating its grade; and have it certificated within five business days of issuing the notice. Volkart Bros., 20 Agri. Dec. 306, 316-17 (1961). By the final days of trading, the financial risks of this approach (the Exchange, it will be remembered, imposed rather substantial penalties if the cotton was not of acceptable grade) had combined with the difficulties in meeting the strict time deadlines to make this solution commercially unfeasible. Several expert witnesses so testified at the hearing before the referee in the Agriculture Department. Brief for Respondents, pp. 68-69, Volkart Bros. v. Freeman, 311 F.2d 52 (5th Cir. 1962) (Hereinafter cited as Respondents' Brief). The Cotton Exchange, in its brief, admitted the fact that arrangements for delivery of uncertificated cotton could not be made at the close of trading, asserting the same to be true if certificated stock were to be delivered. Exchange Brief, p. 36.

47. Respondents' App. p. 35, 37.

48. Volkart Bros., 20 Agri. Dec. 306, 318-19 (1961).

49. Id. at 341. The administrative structure developed in the Agriculture Department for hearing complaints of this nature deserves mention here. The Agriculture Department, on behalf of aggrieved parties (here the squeezed sellers), files a complaint with the Department's Judicial Officer, who, after testimony has been heard by a hearing examiner who recommends a decision, imposes sanctions where necessary. His decision is final unless appealed to a United States Court of Appeals. Flavin, The Functions of the Judicial Officer, United States Department of Agriculture, 26 GEo. WASH. L. Rev. 277 (1958). The Department thus plays the dual role of both prosecutor and judge in actions brought under the various agricultural regulatory statutes, although within the department "there is a complete separation of prosecuting and deciding functions ...." Id. at 284.

50. 311 F.2d at 60 .

51. The court carefully stated the arguments on both sides as to Volkart's intent, and the Judicial Officer's resolution of them, but failed itself to take explicit stand on them. 311 F.2d at 57-58. Further, in order to overturn the Judicial Officer's findings of fact, an explicit holding that they were unsupported by substantial evidence would seem necessary, but was not made by the court. See 4 Davis, Administrative LaW, $\$ 29.01$ (1958). 
that Volkart's behavior was as consistent with an innocent motive as with the guilty intent inferred by the administrative agency. Indeed, the court concerned itself very little with Volkart's actual state of mind. The opinion, in its broadest reach, expresses a finding of law that, irrespective of whether someone in Volkart's position intended, or was able, to manipulate futures prices, such conduct was not punishable as "manipulation" under the Commodity Exchange Act. ${ }^{52}$ Manipulation was punishable, in the court's view, only if it involved creating as well as exploiting market weaknesses. ${ }^{63}$

This narrow reading of the Act, precluding judicial regulation of squeezes, seems predicated on two distinct considerations-a fear of turning the commodities exchange into a "gambling institution," and a preference for the exercise of self-control by the exchanges in an area where judicially enforced regulation might disturb market operation. Thus, the court argued, Volkart's conduct could not be impugned without casting doubt on the legality of the entire functioning of the Cotton Exchange. ${ }^{54}$ Volkart had not itself created the shortage of certificated cotton, it had merely exploited it ;5 consequently its only active "wrong," in the court's view, was its insistence that its futures contracts be satisfied by the delivery of actual cotton. The court disagreed principally with the Judicial Officer's view that Volkart should not have insisted on delivery. ${ }^{56}$ If the purchaser is precluded from insisting on delivery, the court reasoned, it would be tantamount to "excus[ing the sellers] from the performance of their contracts." 67 If that were the case, the court implied, the contract between Volkart and the sellers-and indeed, between all purchasers and sellers on the Exchange-would be no more than a wager on the future price of cotton: a bet by which one party would win if the price of cotton rose by a certain date and the other would win if it dropped. ${ }^{58}$

The court's appraisal of this delivery aspect of futures contracts is not well founded. The Supreme Court has held that trading in grain futures where delivery of actual grain is neither desired nor intended by the parties does not constitute illegal wagering. ${ }^{59}$ The Court recognized that the true economic function of futures trading was to hedge against the possible impact of market fluctuation, and that "it is ... a serious business contract for a legitimate and

52. Thus, the court felt that Volkart's failure to control the spot market was a key factor indicating the culpability of Volkart's conduct. Disregarding commercial reality entirely, it noted that only if the sellers were unable, despite diligence and foresight, to fulfill their delivery obligation could Volkart be held to have created prices "not responsive to the forces of supply and demand." 311 F.2d at 59-60.

53. Id. at 59 .

54. Id. at 60 .

55. Volkart's interest in the stock of certificated cotton was relatively small, see note 43 supra, a fact considered significant by the Court. 311 F.2d at 59.

56. At the same time, the court failed to overrule the finding that Volkart's conduct had not constituted a valid holding out for delivery. Volkart Bros., 20 Agric. Dec. 306, 335-37 (1961).

57. 311 F.2d at 60 .

58. Ibid.

59. See Board of Trade v. Christie Grain \& Supply Co., 198 U.S. 236 (1905). 
useful purpose." 60 Hedging is thus distinguishable from illegal gambling on the same grounds as insurance-that it performs a useful and proper social function. ${ }^{61}$

In addition to the common-law attack on the Department's finding, the court obviously had considerable confidence in the ability of the Exchange to handle such problems. In one manifestation of its preference for exchange selfregulation, the Fifth Circuit relied on the inactivity of the Exchange's control machinery during October, 1957, to indicate that defendant's conduct was not reprehensible. The New York Cotton Exchange would have been in an "excellent position" 22 for discerning high jinks, the court noted, and had a standard technique for countering undue fluctuation-the invitation of merchant members to replace the sellers and make delivery for them. ${ }^{63}$ Dependence on such techniques was implicitly urged by the Exchange, ${ }^{64}$ which submitted an amicus curiae brief predicting dire effects on its operations should its member, Volkart, be found guilty of manipulation in the circumstances of this case. ${ }^{\text {O5 }}$ This approach is also faulty, however. For the Exchange is managed by brokers who deal on it. ${ }^{68}$ And although private control of abuses is often desired, Congress, in enacting extensive regulatory legislation for futures exchanges, delegated control over manipulation to the Agriculture Department, thus apparently deciding that self-control is either an impracticable or an undesirable means of curbing manipulation. ${ }^{67}$

60. Id. at 249.

61. While of course hedging is an aleatory contract, it need not by virtue of that fact be an unlawful wager. For aleatory contracts are by no means uniformly unlawful wagers. Corbin posits three requirements for the illegal gambling agreement: it contains promises performable upon the happening of some fortuitous event; no performance is promised in return for the conditionally promised performance; and, most important, the risk assumed by the promisor is one created by the bargain, not an already existing hazard which is merely being shifted from promisee to promisor. 6A CoRBIN, Conrracts $\$ 1481$ (1961). While each side in the normal hedge on a futures exchange is in essence making the sort of promise outlined in the first two requisites for a wager, the risk involved is not created by the bargain. It is the price risk which a merchant must bear if he does not enter the exchange. The hedging contract is thus a lawful aleatory contract, clearly analogous to an insurance agreement, which is also a bargain based on chance and founded upon the desire to shift already existing risk from promisee to promisor. VANCE, INSURANCE 93 (3d ed. 1958).

62. 311 F.2d at 58.

63. Exchange Brief, p. 17.

64. Exchange Brief, pp. 16-20; see N.Y. Cotron ExchaNge, op. cit. supra note 14, 1115. The Control Committee of the Exchange deals with relatively small problems, such as likely squeezes when longs are obstinate in their desire to hold out for delivery or extraordinarily high prices and some shorts cannot deliver. It asks merchant members of the exchange to replace the shorts who are unprepared for delivery. When a threatened congestion is too great to be handled by the Committee, the Board of Managers may take more severe steps, such as halting trading. The fact that no corrective steps were taken in the present case, however, seems in itself to indicate the shortcomings of exchange regulation of congested situations.

65. Exchange Brief, pp. 60-62.

66. N. Y. CoTton EXCHANGE, op. cit. supra note 14, \$ 1.

67. Since curbs on excessive speculation and resulting fluctuation were the congressional objectives which the prohibition of manipulation was hoped to effect, it seems very probable 
What may have bothered the court most, however, was a fear that regulation of squeezes would interfere too greatly with the operation of the marketplace, posing greater costs than returns. Thus, the court noted, Volkart could be penalized for its conduct "only upon the assumption that the shorts should not be held to their contract obligation to deliver the cotton." 68 If shorts, the sellers of futures contracts, were not required to convey actual cotton in satisfaction of their contracts, the effectiveness of the exchange's operations would be severely impaired. But this analysis of the impact a finding of guilt would have on the exchange is troublesome. The normal commercial expectation of all who deal on the Cotton Exchange is that actual delivery will not be demanded by a purchaser of futures, to whom delivery is rarely economically advantageous. ${ }^{69}$ Where the futures price is significantly higher than the spot price, it will be uneconomical for a holder of futures contracts to take delivery. ${ }^{70}$ Even where a normal futures-spot price relationship exists, the fact that the purchaser usually did not enter the market to obtain the physical commodity and can not be certain of the grade of the commodity he would receive makes delivery impractical. ${ }^{71}$ Finally, the sellers' failure to deliver the commodity where the futures price is markedly below the spot price will not normally inconvenience buyers. Purchasers holding out for delivery to effectuate a spread will only force sellers to bid up prices until they reach their normal conformity with spot prices. At that point, purchasers will again find it profitable to offset, and the delivery requirement thus usually will fulfill its function of keeping prices in line without the sellers having to convey commodities. ${ }^{72}$ The requirement will thus work to stimulate the price rise which makes its en-

that inclusion of squeezes within regulated activity was intended. See note 30 supra; see also 62 Cong. Rec. 9404, 9425, 9427 (1922).

68. 311 F.2d at 60.

69. See notes 12-14 supra, and accompanying text.

70. This seems hardly questionable, since by offsetting, the purchaser would not only avoid the disadvantages of taking delivery on a futures market, but would in addition make a clear profit by liquidating his interest at the high futures price and fulfilling his commodity needs from the spot market.

71. See text accompanying notes 12-14 supra. Admittedly, when a purchaser holds a quantity of contracts roughly equivalent to, or greater than, the amount of certificated commodity available, he can reasonably anticipate, by learning the grades of the certificated stock, the qualities he would receive by delivery. But in that case sellers would find it economical to deliver the amount of certificated cotton on hand rather than bid up the offset price (at least unless short waited until the end of trading on the final day, at which time even this alternative would be difficult). True, where delivery on all contracts would require shorts to undergo the more difficult process of delivering uncertificated commodity-as was the case in Volkart-they may bid up the offset price substantially above the spot price rather than deliver. See note 46 supra. Where that situation exists, however, the holder would be aware that sellers would deliver some uncertificated commodity, whose grades (since he could not know the source of the commodity) he would not know in advance. He would normally, therefore, find it more profitable to offset than to force delivery.

72. Very occasionally, delivery is actually necessary to drive prices back into their normal conformity, perhaps even in several successive months. See note 20 stpra. Such was not the case in Volkart. 
forcement unnecessary. This effect is itself part of the expected market mechanism. While the delivery requirement is essential to market function, then, the daily operation of commodity markets contradicts the view that if the exchange mechanism is to function, sellers must in fact prepare to transfer actual commodities, regardless of the difficulty of doing so. ${ }^{73}$ Indeed, should such preparation regularly occur, it might work considerable harm to market operations by depriving the market of its insurance function, through its conversion into an alternate spot market. ${ }^{74}$ And if the court's analysis were adopted, the absence of judicial control over use of the delivery requirement would only encourage attempts to squeeze.

It is also unclear that a holding against Volkart would have had the effect of removing the delivery requirement from the contract. Even assuming that the finding of manipulation would retrospectively excuse a seller from delivery, it is doubtful that the seller would often avail himself of an opportunity to renege. Knowing neither the purchaser nor his intent, ${ }^{75}$ he can hardly afford to gamble

73. Despite the tenacity with which cotton brokers and the exchanges defend the importance of delivery, Interview with Mr. J. Stewart, former Member, Board of Managers, New York Cotton Exchange, in New York City, June 26, 1963; Exchange Brief, pp. 5-6, commentators appear constantly less willing to credit its significance. See, e.g., Working, Futures Trading and Hedging, 43 Axr. EcoN. Rev. 314, 315-17 (1953). Today, of course, virtually all traders satisfy their contracts by offset. Thus on the Chicago Board of Trade, on which $89 \%$ of all exchange trading in grain in the United States takes place, more than $99 \%$ of all contracts are fulfilled by offset. Hofraran, Future Trading upon Organizen CoMaropity Markets in the United States 106-08 (1932) ; Baer \& Saxon, Commodity ExCHANGES ANd Futures TRAdING 210 (1949). Significantly, Volkart was the sole trader to take delivery on his contracts in the October, 1957, cotton future. Volkart Bros., 20 Agri. Dec. 306,319 (1961). Even assuming, however, that the delivery requirement is so valuable that it should be rigidly enforced, the decision in the present case, considering the area of possible manipulation it leaves unregulated, seems a less than ideal way to safeguard the requirement. Affirmance "of the Judicial Officer's decision, on the other hand, might have pressed exchanges which wished to retain the vitality of this requirement to modify and improve their by-laws with regard to it. Thus, the cotton exchanges might enact a regulation which granted longer periods after the final days of trading for delivering certificated cotton or for getting uncertificated cotton approved. In addition, replacement by the seller of unsatisfactory cotton might be allowed, which would reduce the danger of extensive contract damages. Sellers would then be less pressured when delivery was apparently desired by buyers, and would have sufficient time to make preparations for and satisfy their contracts by delivering.

74. If sellers prepared for delivery to a significant degree, many would purchase deliverable commodities early in delivery month. And having done so, they might issue delivery notices in large quantities and simply convey their goods to purchasers rather than dispose of them on the spot market after offsetting their futures. (This would be especially likely where spot prices are relatively low, since sale on the spot market would be unprofitable.) This result would hardly be satisfactory to most buyers, who would be burdened by being forced to take delivery, and it could lead them to sell heavily and quickly during the final month, thus generating further price instability on the exchange. After they had learned of this liklihood, however, buyers might cease using the exchange for insurance purposes, and rely on it as nothing more than a spot market in which delivery of goods was guaranteed by the exchange clearing house.

75. Since the clearing house substitutes itself for each party to a contract vis-a-vis the other party, a seller cannot know to whom he may owe delivery. See note 17 supra. 
substantial penalties on the result of a subsequent administrative determination of manipulation vel non. Finally, the effectiveness of the delivery requirement would not be lessened in situations where the futures-spot price relation is already dislocated. Proscribing squeezes of the Volkart variety would principally affect large traders capable of affecting the market by intentional action. But when a dislocation exists, it is the market-compelled reaction of small speculators and hedgers which assures the return of prices to their normal relationship. ${ }^{76}$ In sum, the Judicial Officer's decision may be seen, not as destroying the vitality of the contract, but as reading its terms in a manner consistent with commercial practice and existing regulation. In effect, the literal terms of the instrument are modified to include a "good faith" provision, that the demand for delivery arise from some impetus other than the hope of capitalizing on seller expectations. This, of course, raises the uitimately difficult problem: determining from trader action whether delivery was sought in good faith. This determination forms the analytic nub of the problem of regulating squeezes, which the court avoided by exempting squeezes from regulation altogether.

The court's position is justified only if the facts from which intent must be inferred are always as consistent with an innocent intent and the ordinary functioning of the exchange as with a manipulative intent. ${ }^{77}$ While some miscreants may inevitably escape under the cover of ambiguity, this is not a sound reason for refusing to punish those who can not. Intent will sometimes appear clearly. There may be direct evidence of it. ${ }^{88}$ And there may be some acts nonambiguous in indicating manipulative intent, which can serve to aid a decision maker willing to prosecute manipulators whenever manipulation can be clearly established. Factors which necessarily are ambiguous in their implications will of course fail to serve this purpose. If a trader's prolonged refusal to offset holdings can reasonably be characterized as a hedge for a spot sale not covered by a corresponding spot purchase until late in the delivery month, a court should not infer an intent to manipulate. Equally, a trader's actions might be interpreted as an ordinary reaction to unusually low futures prices. In this

76. See Working, Futures Trading and Hedging, 43 Ar. Econ. Rev. 314, 325 (1953). Working believes that a great deal of hedging is based on merchants' beliefs as to the current relation of spot and futures prices and the likely future course of that relation.

77. The inference must be, it should be remembered, based only on a preponderance of evidence, and need not be compelled beyond any reasonable doubt. However severe may be the administrative sanctions placed on manipulative conduct, there is no question that they are remedial rather than penal in nature, designed to protect honest traders and enforce adherence to the act's provisions. Thus the more rigid burden of proof need not be satisfied. See Nichols v. Secretary of Agriculture, 131 F.2d 651, 659 (1st Cir.) rev'd on other groutnds, 136 F.2d 503 (1st. Cir. 1943) ; Board of Trade v. Wallace, 67 F.2d 402 (7th Cir. 1933). See also Wright v. SEC, $112 \mathrm{~F} .2 \mathrm{~d} 89,94$ (2d Cir. 1940).

78. This occurrence, of course, is extremely rare. Even in cases such as Great Western Food Distribs., Inc. v. Brannan, 201 F.2d 476, 484 (7th Cir.), cert. denied, 345 U.S. 997 (1953) in which "direct" evidence of intent was found, it was clearly far more ambiguous than the court held it to be. See Comment, Manipulation of Commodity Futures PricesThe Great Western Case, 21 U. CHI. L. REv. 94, 109 (1953). 
situation, it is to be anticipated that traders will hold either for delivery, if the imbalance is a protracted one, or until the closing of the futures-spot price gap. In short, where a refusal to offset is consistent with normal market conduct, such a refusal cannot be the basis for a finding of manipulation.

But other circumstances are not so ambiguous with respect to intent. Where a speculator, who has no commodity to insure, holds out to a degree unexplainable by the current price relationships, no justifying factor appears. Similarly for the hedger who takes futures contracts beyond his needs for hedging, or who buys when hedging principles suggest he should sell. Another indication of manipulative intent would be the making of arrangements to dispose of any commodity which might be received. Such conduct would imply that the trader expected some deliveries to be forced by his operations, but that he did not desire to receive actual quantities of the commodity. ${ }^{79}$ In addition, a court should examine critically any conduct capable of misleading sellers as to a purchaser's intent to hold out for delivery, such as setting prices for liquidation during delivery month slightly above the market level. Where these factors exist, any inference that the behavior was inadvertent would tend to be defeated if the trader were highly experienced in market operations; he would then know and, inferentially, wish the consequences of his acts. If the trader held a substantial bloc of outstanding contracts or obligations when the conduct complained of occurred, and if the market had previously behaved normally, the inference that he had acted in bad faith would be strengthened. As in antitrust regulation, size itself might serve to warn that private control was responsible for abnormal market conduct. ${ }^{80}$

The facts of the Volkart case indicate a situation in which intent to manipulate could have been found without undue interference with the market's ordinary operations. Volkart was an experienced brokerage firm, and consequently it must have realized the inflationary effects that late holding of its interest would have. It must also have known that most sellers would not expect a demand to deliver and were hence vulnerable to a squeeze. Nor did Volkart's protestations that it actually desired delivery appear to have much merit. Volkart could not reasonably have expected to receive the qualities of cotton it needed for its operations. 81 Indeed, though it might, as a large-scale merchant, have taken delivery of many grades, most of the cotton it in fact received must have been unsatisfactory, since it delivered most of it in ful-

79. The problem of ridding oneself of unwanted deliveries after the collapse of high prices caused by a corner or squeeze, often termed "burying the corpse," has often disturbed seasoned and not so scrupulous traders. See HUbBard, CotTon aND the CotTon Market 393-94 (1927). One method of avoiding this problem consists in selling substantial quantities of contracts in the next delivery month and fulfilling them by delivering the commodities received as incidents of the corner or squeeze. Comment, Manipulation of Commodity Futures Prices-The Great Western Case, 21 U. CHI. L. Rev. 94, 101 (1953).

80. See Neale, The Antitrust Laws of the U.S.A. 109-16 (1960).

81. Indeed, there is little question that Volkart knew it could not receive delivery on its entire open interest. An officer of the firm estimated that it had received delivery on about one-half its contracts, which he apparently considered a high percentage. Interview with Kurt Muller, Vice-President, Volkart Bros., Inc., Respondents' App. at 82. 
fillment of its obligations in December futures. ${ }^{82}$ And its action throughout October in setting prices, albeit above the market price, on all its open contracts would seem to indicate more a willingness to offset than a desire to receive actual. cotton. ${ }^{83}$ Further, there seems little likelihood that the firm's operations were merely unterminated hedging in October futures; during late September and October its futures operations were not equivalent and opposite to its transactions. On some days it actually bought both spot cotton and futures. ${ }^{84}$ Moreover, as a hedger Volkart had no substantial need to purchase October futures since its stocks of cotton far outmatched its sales commitments, a position which to a strict hedger would call for a substantial futures sales. ${ }^{85}$ Volkart obviously was not hedging, then, nor is it probable that it was simply holding out for delivery. Rather, it seems likely, given the firm's experience in the market and its knowledge of the sellers' probable expectations, that it was intent on creating a squeeze, one from which it eventually reaped a substantial profit. ${ }^{86}$

The difficulty with the Fifth Circuit's treatment of the problem was its apparent assumption of an either-or position in treating the delivery requirement. The alternatives are not so stark as the ability or disability of traders arbitrarily to stand on their literal contract rights; the presence of federal market regulation proscribing manipulation suggests that limiting enforcement of the delivery requirement to good faith situations is consistent with the maintenance of a soundly operating commodity exchange.

82. Id. at 63.

83. Volkart set prices for liquidation from October 1 through October 14. Id. at 35, 37.

84. Respondents' Brief at 951 .

85. Both its domestic and its foreign stocks outnumbered its commitments by substantial amounts. Volkart Bros., 20 Agri. Dec. 306, 324-25 (1961).

86. The Agriculture Department arrived at the conclusion, undisputed by the Court of Appeals, that Volkart had profited by approximately $\$ 21,230$ from the rise in the final day of trading. Volkart Bros. v. Freeman, 311 F.2d 52, 58 (5th Cir. 1962). 